\title{
The effect of electronic audit and feedback in primary care and factors facilitating effectiveness: a systematic review.
}

\author{
Steve Van den Bulck ${ }^{1}$, David Spitaels ${ }^{1}$, Bert Vaes ${ }^{1}$, Geert Goderis ${ }^{1}$, Rosella Hermens ${ }^{1}$, and \\ Patrik Vankrunkelsven ${ }^{1}$ \\ ${ }^{1}$ KU Leuven Academic Center for General Practice
}

May 5, 2020

\begin{abstract}
Rationale, aims and objectives: Little is known about the effect of electronic audit and feedback (A\&F) in primary care and its features affecting intervention effectiveness. The aim of this systematic review is: 1) to assess electronic A\&F's effectiveness in primary care and 2) to investigate facilitating factors of electronic A\&F in primary care, as proposed in previous research. These factors are the use of benchmarks, frequency, cognitive load and evidence-based aspect of the feedback. Methods: The authors searched MEDLINE, Embase, CINAHL and CENTRAL from 2010 onwards by replicating the search strategy provided in the last Cochrane review on A\&F. Two independent reviewers assessed the records for their eligibility, performed the data extraction and evaluated the risk of bias of the included studies using a tool provided by Cochrane. Results: Our search resulted in 8,744 records, including the 140 RCTs from the last Cochrane Review, of which 431 full-text articles were assessed for their eligibility. Twenty-nine articles were included, of which 22 studies (76\%) showed an effect of the electronic A\&F intervention. Of these, only 3 studies (10.5\%), targeting the quality of diabetes care and the prescription of antibiotics by dentist \& physicians, met all the investigated feedback features and were effective. There was a high heterogeneity in the results and the design of the A\&F interventions, causing a meta-analysis to be unreliable. Conclusion: This systematic review included 29 articles describing an electronic A\&F intervention in primary care, of which 22 studies (76\%) showed an effect of the intervention. It was not feasible to compare the different electronic A\&F interventions and their facilitating factors because they were designed and implemented very diversely. Developing a framework or methodology for automated A\&F interventions in primary care could be useful for investigating future interventions although further research is necessary.
\end{abstract}

\section{Introduction}

Audit and feedback (A\&F) is a well-known healthcare intervention, which can be defined as 'any summary of clinical performance of healthcare providers over a specific period in time'. ${ }^{1}$ A\&F has proven to be effective and the intervention generally leads to small but potentially important improvements in professional practice. ${ }^{2}$ For $\mathrm{A} \& \mathrm{~F}$ to be effective a number of features, such as the feedback frequency, are known to be important and certain modifiable design elements have been identified to help understand the differences in $\mathrm{A} \& \mathrm{~F}$ interventions and to indicate gaps in reporting of interventions. ${ }^{2,3}$ Previous work has also defined theory-informed hypotheses as a foundation for the development of future A\&F interventions and suggestions for improving the interventions' effectiveness have been published. ${ }^{4-6}$ These hypotheses can be classified based on different aspects of the intervention. For example, A\&F interventions can be evaluated based on recipient related aspects of the intervention, the behavior that was targeted, delivery and content of the feedback. ${ }^{4,5}$ For feedback content, features such as the use of benchmarks for comparative purposes and of feedback with a low cognitive load could be important in an A\&F intervention ${ }^{4}$ Furthermore, the credibility of the feedback, for example feedback based on good quality evidence, has also been suggested to play an 
important role because of its potential to increase recipient's trust in the feedback. ${ }^{4}$ However, the importance of these hypotheses and feedback features in the design of an A\&F intervention needs to be investigated. ${ }^{4,5}$

In addition to the many studies being conducted to examine why and when $\mathrm{A} \& \mathrm{~F}$ are of use, research is being published on creating tools to facilitate feedback, especially via an electronic medium. ${ }^{7-10}$ Electronic A\&F can be defined as 'the utilization of interactive computer interfaces to provide clinical performance summaries to healthcare professionals. ${ }^{8,11,12}$ With the evolution in health information technology, electronic A\&F based on data stored in the electronic health record (EHR) offers a promising evolution in A\&F interventions. ${ }^{13,14}$ By automating an $\mathrm{A} \& \mathrm{~F}$ intervention and providing the feedback in electronical form to the healthcare provider, the number of patients whose quality of care can be evaluated could increase drastically, which in turn could lead to a better quality of care. ${ }^{15}$ Large data repositories are already available in several countries and could be useful for this purpose. ${ }^{16-18}$ These databases collect routine primary healthcare data, anonymized at the source and use it to address many research questions of interest. ${ }^{19}$ EHR-extractable quality indicators are also available and can be used in an electronic $A \& F$ intervention to evaluate and improve the care for different diseases in primary care. ${ }^{20,21}$

A previous systematic review on electronic A\&F performed in a primary care and hospital context investigated the effectiveness and use of behavioral chance mechanism underlying these electronic A\&F interventions. ${ }^{12}$ However, due to the high heterogeneity in the included studies, the effect of the interventions was highly variable and inconclusive. ${ }^{12}$ Furthermore, there is evidence that new research is not benefiting the field and that new trials fail to explore factors responsible for A\&F effectiveness ${ }^{22}$, and more in particularly that of electronic A\&F. For improving and understanding future electronic A\&F interventions it is thus important that these factors are identified and that we understand why electronic A\&F work so that an intervention can be designed that is best suited for its needs. ${ }^{23}$ In addition, little is known about electronic $\mathrm{A} \& \mathrm{~F}$ and its features that are useful for optimizing an electronic A\&F intervention in primary care. The aim of this systematic review is therefore: 1) to assess whether electronic A\&F is effective for improving health provider performance and healthcare outcomes in primary care and 2) to uncover facilitating factors that contribute to the effectiveness of electronic A\&F in primary care, as proposed in previous research.

\section{Methods}

\section{Background}

The protocol of this systematic review is described in detail on PROSPERO: https://www.crd.york.ac.uk/prospero/display_record.php?ID=CRD42018089069

Our inclusion \& exclusion criteria and our search strategy were based on the Cochrane review on A\&F. ${ }^{2}$ Although this Cochrane review examined A\&F in primary and non-primary care, we opted to use the same strategy and criteria and applied our extra inclusion \& exclusion criteria (primary care and electronic A\&F) after the search. Our methods report adheres to guidelines of the Preferred Reporting Items for Systematic Reviews and Meta-Analyses (PRISMA) statement. ${ }^{24}$ (see Appendix 1)

\section{Inclusion and exclusion criteria}

Randomized controlled trials in which the intervention was set up for primary healthcare providers responsible for patient care were included. The interventions studied in the included RCTs had to be electronic A\&F, either alone or as a core element of a multifaceted intervention. Electronic A\&F was defined as 'any summary, which was delivered electronically, of clinical performance of healthcare over a specified period of time'. To distinguish between a core and not core element of an intervention, the same criteria used in the Cochrane review of 2012 on A\&F were adopted. Non-core interventions were classified as those that could easily be offered in the absence of the $\mathrm{A} \& \mathrm{~F}$ component. ${ }^{2}$

As in the Cochrane review, studies in which real-time feedback was provided during procedural skills were excluded as well as studies that examined feedback on performance with simulated patient interactions or 
studies in which the term feedback would be best classified as 'facilitated relay' of patient-specific clinical information. ${ }^{2}$ Randomized controlled trials that were not conducted in a primary care setting were also excluded. Studies without full-text availability (e.g. conference abstracts) were excluded. Studies were also excluded if they lacked clarity as to whether feedback was delivered electronically.

\section{Searches}

We replicated the search strategy provided in the Cochrane review on A\&F. ${ }^{2}$ Although our systematic review only addressed randomized controlled trials about electronic A\&F in primary care, we opted to use exactly the same search terms as those used in the Cochrane review (see Appendix 2) but used an Elsevier-Embase search instead of an Ovid-Embase search (see Appendix 3).

Our search included MEDLINE (Ovid) (2010 -October Week 4 2018) (searched 25 November 2018), EMBASE (Elsevier) (2010 - October Week 4 2018) (searched 25 November 2018); CINAHL (Ebsco) (2010 -October Week 4 2018) (searched 31 October 2018) and the Cochrane Central Register of Controlled Trials (CENTRAL) (2010 - February Week 2 2019) (searched 14 February 2019). These searches were conducted from 2010 until the beginning of November 2018, based on the earliest publication date of papers found during scoping searches. The CENTRAL database search had to be repeated at a later date due to technical issues. Our search started on 1 January 2010, in order to ensure some overlap with the results from the Cochrane review from 2012 and to avoid articles being missed. The search strings are available in Appendix 2 .

In addition the 140 RCTs included in the Cochrane review were added to our search results. ${ }^{2}$

\section{Data collection and analysis}

Selection of studies

After removing duplicate references, all references were screened for title and abstract independently by two review authors (SVDB and DS). Randomized controlled trials were classified as inclusion, doubt or exclusion. Disagreements were resolved by discussion. The full text of all articles that were classified as doubt and inclusion were obtained. Two review authors (SVDB and DS) independently read all full manuscripts, and re-applied the inclusion criteria. If there was still no consensus or if doubt remained after reading the full text, a third review author (PV) was consulted to give his opinion. If doubt remained on the form of delivered feedback after consulting the third reviewer, the article was excluded.

\section{Data extraction}

Two independent reviewers (SVDB and DS) used a data extraction sheet to extract the data from the included studies. This data extraction sheet was tailored based on the Cochrane handbook and the EPOC data collection checklist. ${ }^{2526}$ A separate data extraction file was made for dichotomous and for continuous data.

Audit and feedback features which are known to be important or were suggested by other authors as potentially facilitating A\&F interventions, were also incorporated on our data extraction sheet. ${ }^{2-5}$ These features were: feedback frequency, evidence-based aspect of the feedback (yes, no or unclear), the use of benchmarks as comparisons in the feedback (yes, no or unclear) and the cognitive load of the feedback (does the feedback have a low cognitive load: yes, no or unclear). Interventions with feedback consisting of many graphs and/or text were considered as having a high cognitive load, while interventions with few graphs and no unnecessary in-depth elements or text, were considered as having a low cognitive load.

Discrepancies were resolved by discussion. If no consensus was reached, another reviewer (PV) was consulted. In case of missing data the first author was contacted. For each article standard data were extracted, such as authors, year of publication \& the year of data collection, study design, number of participants, type of participants, duration of the trial, type of intervention, how this intervention was organized (e.g. No. randomized participants, providers, delivery,...) and outcome (including dichotomous, continuous or other 
outcome). (see Appendix 4 and 5 for the data extraction sheets for continuous and dichotomous outcomes, respectively)

Data analysis

If appropriate, a meta-analysis was carried out. If not, the results were described narratively. A metaanalysis was carried out if there were at least two studies with a similar intervention, in a similar population, which addressed similar outcomes and if sufficient data were available. If high heterogeneity was found, the meta-analysis was not reported since the results would be unreliable.

\section{Risk of bias assessment}

Included in the data extraction sheet was a list used by two independent reviewers (SVDB and DS) to assess the risk of bias. This list was tailored based on the Cochrane Collaboration tool for assessing the risk of bias in randomized trials. ${ }^{27}$ Discrepancies in the findings were solved by consensus or by consulting a third reviewer (PV) if consensus was not possible. For our risk of bias summary, blinding of participants and personnel (performance bias) was not considered a key domain since the nature of an A\&F intervention makes blinding difficult. The risk of performance bias was therefore not used to calculate the summarized risk of bias of the different studies. However, all of the other forms of bias were considered key domains and if one of them had a high or an unclear risk of bias, the summary was considered as having a high or an uncertain risk of bias, respectively.

\section{Results}

\section{Searches}

In this systematic review, a total of 12,054 records were identified through database screening. The 140 articles from the Cochrane review (on A\&F in primary and non-primary care) were also included, which resulted in a list of 8,744 records that were screened after removing the duplicates. (see Figure 1)

\section{Data collection and analysis}

\section{Selection of studies}

In total, 8,313 records were excluded because they did not meet the inclusion criteria. Most of them were excluded because there was no (electronic) A\&F intervention or because they were not conducted in a primary care setting. A total of 431 full-text articles were assessed for eligibility and 402 articles were excluded (see Figure 1). The total number of studies included through database searching was $23^{28-50}$ and an additional $6^{51-56}$ articles published before 2010 were included from our screening of the Cochrane review published in 2012. One article was available as a conference abstract in the 2012 Cochrane review but the full-text article was included, which was identified through our database search and published in 2012. ${ }^{50}$

Insert Figure 1: PRISMA flow-chart

Description of studies and electronic feedback features

The standard data we extracted showed 12 articles (41\%) with continuous ${ }^{28,32-35,37-39,43,51,54,56}$ and 17 articles $(59 \%)$ with dichotomous outcome measures $29-31,36,40-42,44-50,52,53,55$. There was a high heterogeneity in the outcome measures of the trials and a wide range of clinical conditions were targeted by the interventions. Examples of outcome measures included the proportion of patients in compliance with guidelines for dental problems, the total number of antibiotic items dispensed, a composite measure of clinically significant depression, etc. (see Table 1 and 2) The targeted clinical conditions included for example diabetes, depression, preventive medicine, hypertension management, etc. (see Table 1 and 2). The trials usually had a cluster RCT design although 5 studies $(17 \%)$ used an RCT design ${ }^{34,36,37,52,55}$. The interventions mostly included general physicians but there were also 2 trials (7\%) aimed at dentists ${ }^{35,54}$ and 1 trial (3.5\%) at pharmacists ${ }^{36}$. Patients were mostly the unit of analysis (19 studies, $65.5 \%$ ), but some studies also used the providers (7 
studies, 24\%) or the distribution/prescriptions of medication (2 studies, $7 \%$ ) as the unit of analysis. Finally, one study (3.5\%) analyzed both data on patient and provider level (see Table 1 for continuous outcomes and Table 2 for dichotomous outcomes).

Insert: Table $1+$ table 2

The data on the different features of electronic feedback showed 12 studies (41\%) where feedback was provided less than monthly $29,34,35,37,40,42,43,47,50,51,53,54,11$ studies $(38 \%)$ where the frequency of the feedback was unclear ${ }^{30,32,33,41,44-46,48,52,55,56}, 4(14 \%)$ with feedback provided monthly ${ }^{28,38,39,49}, 1$ (3.5\%) with weekly feedback ${ }^{31}$ and 1 study $(3.5 \%)$ where feedback was delivered only once ${ }^{36}$. In 19 studies $(65.5 \%)$ the feedback was evidence-based $28,31-36,39-43,45,46,49,51,54-56$. The evidence-based quality of the feedback was unclear in 9 studies $(31 \%)^{29,30,37,38,44,47,50,52,53}$ and 1 study $(3.5 \%)$ had a low evidence base of the feedback ${ }^{48}$. The use of benchmarks as a comparison in the feedback was present in 20 studies $(69 \%)^{28,29,32,34-36,39-41,43-47,49,51-53,55,56}$, unclear in 7 (24\%) $30,31,37,42,48,50,54$. Only 2 studies $(7 \%)$ did not use benchmarks as a comparison in their feedback ${ }^{33,38}$. The cognitive load of the feedback was low in 12 studies (41\%) $29,32,33,35,37,39,41,43,46,49,53,56$, high in $3(10.5 \%)^{34,36,40}$ and unclear in 14 studies $(48.5 \%)^{28,30,31,38,42,44,45,47,48,50-52,54,55}$. Finally, the direction of change was to increase behavior in 18 $(62 \%)^{28,30,33,36,38,39,41,42,45-48,51-56}$ and to decrease behavior in eleven studies $(38 \%)^{29,31,32,34,35,37,40,43,44,49,50}$. (see Table 3 for studies with continuous outcomes and Table 4 for studies with dichotomous outcomes)

Insert: Table $3+$ table 4

Results data analysis

Twenty-two studies $(76 \%)$ showed an effect of the intervention ${ }^{28-31,35-41,43-46,48,50-53,55,56}$, of which 3 studies only had a partial effect $(10.5 \%)^{36,41,51}$, and $7(24 \%)$ without any significant effect ${ }^{32-34,42,47,49,54}$. There were 3 studies $(10.5 \%)^{35,39,43}$ that met all the different characteristics of the feedback we examined (the feedback was evidence-based, provided more than once with the use of benchmarks as a comparison and with a low cognitive load) and that were effective while 1 study (3.5\%) with the same feedback features showed no effect. 49

Of these 3 studies with an effect of the intervention, Elouafkaoui et al. investigated the effectiveness of an electronic A\&F intervention on the prescription of antibiotics by dentists. This resulted in a $5.7 \%$ reduction (95\% CI $-1.1 \%$ to $-10.2 \%)$ in the antibiotics prescription rate in the intervention group relative to the control group. ${ }^{35}$ Furthermore, Hayashino et al. evaluated the effectiveness of a multifaceted intervention, consisting of monthly feedback reports using the Achievable Benchmark of Care method, on the technical quality of diabetes care by primary care physicians. This improved the quality of care with 19.0\%-point (95\% confidence interval 16.7\%- to $21.3 \%$-point; P < 0.001). ${ }^{39}$ Finally, Gerber et al. studied the effect of a multifaceted intervention, consisting of education and quarterly $\mathrm{A} \& \mathrm{~F}$, on the prescription of antibiotics for acute respiratory infections by primary care pediatricians and showed that broad-spectrum antibiotics prescription decreased from $26.8 \%$ to $14.3 \%$ (absolute difference, 12.5\%) among intervention practices vs from $28.4 \%$ to $22.6 \%$ (absolute difference, $5.8 \%$ ) in controls. ${ }^{43}$

However, because of the high heterogeneity of our results no meta-analysis was performed since the results would be inconclusive.

\section{Risk of bias assessment}

There was a high risk of performance bias in 17 of the included studies (59\%), while the risk of selection and detection bias was minimal. The risk of both attrition and reporting bias was high in 6 different studies (21\%). (see figure 2). To summarize, 4 studies (14\%) had a low overall risk of bias ${ }^{28,30,34,40}$, while 12 studies (41\%) had a high risk ${ }^{29,32,37-39,41,45-47,51-53}$ and 13 studies (45\%) had an unclear risk of bias. ${ }^{31,33,35,36,42-44,48-50,54-56}$ (see Figure 3)

Out of the 4 articles with a low risk of bias summary, 3 included feedback features which are known to be effective (feedback provided more than once) or were suggested as potentially important for improving A\&F 
interventions (evidence-based feedback with the use of benchmarks).

Insert Figure 2: Risk of bias graph: review authors' judgements about each risk of bias item presented as percentages across all included studies.

Insert Figure 3: Risk of bias summary: review authors' judgements about each risk of bias item for each included study.

\section{Discussion}

\section{Principal findings and comparison with previous work}

This systematic review identified 29 articles describing an electronic A\&F intervention in primary care. Overall, 22 studies $(76 \%)$ showed an effect of the intervention on outcome measures such as the change in systolic blood pressure, medication prescriptions, the proportion of patients with a medication error and the change in the proportion of patients treated with oral anticoagulants. Three of these studies (10.5\%) included all the features of the feedback that were investigated (the feedback was evidence-based, had a low cognitive load, used benchmarks as a comparison and was provided more than once). ${ }^{35,39,43}$ The interventions in these 3 studies targeted behaviors such as prescribing antibiotics for infections by dentists, improving the technical quality of diabetes care by primary care physicians and prescribing antibiotics for respiratory tract infections by primary care pediatricians. However, there was a high heterogeneity in the primary outcomes of these studies and the electronic A\&F interventions were designed very diversely with various feedback features, making a meta-analysis unreliable. Because of this, we were also unable to make generalizable claims about the importance of the feedback features we examined. Furthermore, only 4 studies (14\%) had a low risk of bias summary, not counting performance bias. In addition, these 4 articles had been published more recently from 2016 onwards, possibly indicating some new evidence toward a maturing methodology in the A\&F research field. ${ }^{28,30,34,40}$

In general these findings confirm the overall stagnation in A\&F research, as described by other authors ${ }^{22}$ and show there is insufficient research on implementation so as to further the field and build further on existing knowledge. ${ }^{23}$ Previous work showed that feedback is best provided more than once and our findings indicate this is only the case in 12 of the included studies (41\%). However, 3 out of 4 articles with a low risk of bias summary that were from a more recent publication date, included feedback features which are known to be effective (feedback provided more than once) or were suggested to be potentially important in improving $\mathrm{A} \& \mathrm{~F}$ interventions (the feedback was evidence-based and included use of benchmarks as a comparison). 28,34,40 Hence, despite the stagnation described in the past, more recent publications were of high quality and built on existing research, which could indicate a trend towards reinvigorating A\&F research. These findings also correspond with the latest innovation to investigate the effectiveness of A\&F interventions, the implementation laboratories. ${ }^{57}$ Implementation laboratories are being developed to promote collaborative research between healthcare system partners \& researchers and to create an opportunity for experimentation. These laboratories thus aim to produce generalizable knowledge about how to optimize A\&F. Internationally, these implementation laboratories are united in a 'meta-laboratory' approach to facilitate cumulative research in the field of $\mathrm{A} \& \mathrm{~F}$ research. ${ }^{57}$

Although A\&F, and more precisely electronic A\&F, were studied extensively in primary care, a meta-analysis to pool the results and produce some generalizable data was not feasible. This emphasizes the difficulties in designing complex healthcare interventions and the need for a framework and a well-defined research agenda when setting up electronic A\&F trials so that interventions can be reproduced and compared. ${ }^{23,58}$ Designing a methodology for developing generalizable automated A\&F interventions in primary care could be useful for this purpose since automated quality assessment based on EHR data offers promising prospects if the challenges are answered. ${ }^{15}$ Another important challenge when using EHR data is the completeness of these

data. Provision of data quality feedback could improve this. ${ }^{59}$ After all, if the data stored in the EHR are not complete, using them for an electronic A\&F intervention will produce unreliable results. 
Large data repositories, such as those of the Dutch institute for research of healthcare (NIVEL), the British Royal College of General Practitioners (RGCP) Research and Surveillance Centre (RSC) network, and the Belgian INTEGO database, have already been available for many years in primary care $17,60,61$. Using the facilities of these institutes in a well-designed trial with a standardized methodology could address some of the problems in evaluating the effectiveness and features of electronic A\&F interventions. In this respect, recent research indicates the need for an evolution from a two-arm trial of A\&F versus control to head-to-head trials of various $A \& F$ variants to measure small differences in effectiveness of different A\&F features. ${ }^{57}$ Such trials need to be sufficiently powered, requiring large sample sizes which could be provided by these large primary care data repositories. ${ }^{57}$ However, further research, mainly into describing a methodology for an automated and EHR-based A\&F intervention in primary care, is necessary. Designing and using a standardized methodology to create automated A\&F interventions based on EHR data could allow comparison of future electronic A\&F interventions. They could be used to investigate different features of the intervention, which in turn could advance the field of A\&F research in general.

\section{Strengths and limitations}

To our knowledge, this is the first systematic review that investigated electronic A\&F only in primary care. One of the strengths of this review is our search, which was identical to the last Cochrane review. By replicating the search strings of the Cochrane review, followed by screening abstracts and full-text articles based on our in- and exclusion criteria, this review had a broad basis. Our search led to a higher number of articles that were screened for in-or exclusion based on abstract $(n=8744)$ and on full-text $(n=431)$ compared with that of a previous review performed in a primary and non-primary care setting. ${ }^{12}$ This method reduced the risk that relevant articles were missed.

Our review also has several limitations. Because our results showed high heterogeneity, no meta-analysis could be meaningfully performed and no generalizable data could be produced. Therefore, results were described narratively. Our definition of electronic A\&F was strict and articles for which it was unclear if the A\&F intervention was performed electronically were excluded, thus possibly missing some relevant articles. However, compared with a previous review on electronic A\&F, which included 7 articles, our review included a higher number of articles since studies in which electronic A\&F was part of a multifaceted intervention were also withheld. ${ }^{12}$ Finally, for the calculation of our risk of bias summary every form of bias was considered as a key domain, except for performance bias, which may have produced too severe an overall risk of bias evaluation.

\section{Conclusion}

This systematic review included 29 articles describing an electronic A\&F intervention in primary care, of which $76 \%$ showed an effect of the intervention on outcome measures such as change in systolic blood pressure, medication prescriptions, proportion of patients with a medication error and change in the proportion of patients treated with oral anticoagulants. Approximately $10 \%$ of the studies included all the facilitating feedback conditions we examined and showed an effect of the intervention, particularly on the prescription of antibiotics by dentists \& primary care physicians and on the technical quality of diabetes care. There was a high heterogeneity in the results, making a meta-analysis unreliable. The design of the A\&F interventions showed a great variability and overall, our results confirmed the previously described stagnation in the field of A\&F research. However, 4 recent publications with a low risk of bias showed a positive evolution in the design and description of $\mathrm{A} \& \mathrm{~F}$ interventions. Developing a framework or methodology for automated A\&F interventions in primary care could be useful for necessary future research.

\section{References}

1. Jamtvedt G, Young JM, Kristoffersen DT, O'Brien MA, Oxman AD. Audit and feedback: effects on professional practice and health care outcomes. The Cochrane database of systematic reviews. 2006(2):Cd000259. 
2. Ivers N, Jamtvedt G, Flottorp S, et al. Audit and feedback: effects on professional practice and healthcare outcomes. The Cochrane database of systematic reviews. 2012;6:Cd000259.

3. Colquhoun H, Michie S, Sales A, et al. Reporting and design elements of audit and feedback interventions: a secondary review. BMJ quality \& safety. 2016.

4. Colquhoun HL, Carroll K, Eva KW, et al. Advancing the literature on designing audit and feedback interventions: identifying theory-informed hypotheses. Implementation Science. 2017;12(1):117.

5. Brehaut JC, Colquhoun HL, Eva KW, et al. Practice Feedback Interventions: 15 Suggestions for Optimizing Effectiveness. Annals of internal medicine. 2016;164(6):435-441.

6. Brown B, Gude WT, Blakeman T, et al. Clinical Performance Feedback Intervention Theory (CP-FIT): a new theory for designing, implementing, and evaluating feedback in health care based on a systematic review and meta-synthesis of qualitative research. Implementation science : IS. 2019;14(1):40.

7. Mould DR, Upton RN, Wojciechowski J. Dashboard Systems: Implementing Pharmacometrics from Bench to Bedside. The AAPS Journal.2014;16(5):925-937.

8. Waitman LR, Phillips IE, McCoy AB, et al. Adopting real-time surveillance dashboards as a component of an enterprisewide medication safety strategy. Jt Comm J Qual Patient Saf. 2011;37(7):326-332.

9. Khairat SS, Dukkipati A, Lauria HA, Bice T, Travers D, Carson SS. The Impact of Visualization Dashboards on Quality of Care and Clinician Satisfaction: Integrative Literature Review. JMIR Hum Factors. $2018 ; 5(2): \mathrm{e} 22$.

10. Karami M, Langarizadeh M, Fatehi M. Evaluation of Effective Dashboards: Key Concepts and Criteria. Open Med Inform J.2017;11:52-57.

11. Brehaut JC, Eva KW. Building theories of knowledge translation interventions: use the entire menu of constructs. Implementation science : IS. 2012;7:114.

12. Tuti T, Nzinga J, Njoroge M, et al. A systematic review of electronic audit and feedback: intervention effectiveness and use of behaviour change theory. Implementation Science. 2017;12(1):61.

13. Patel S, Rajkomar A, Harrison JD, et al. Next-generation audit and feedback for inpatient quality improvement using electronic health record data: A cluster randomised controlled trial. BMJ Quality and Safety. 2018;27(9):691-699.

14. Gulliford MC, Prevost AT, Charlton J, et al. Effectiveness and safety of electronically delivered prescribing feedback and decision support on antibiotic use for respiratory illness in primary care: REDUCE cluster randomised trial. BMJ (Clinical research ed).2019;364:1236.

15. Roth CP, Lim YW, Pevnick JM, Asch SM, McGlynn EA. The challenge of measuring quality of care from the electronic health record.American journal of medical quality : the official journal of the American College of Medical Quality. 2009;24(5):385-394.

16. Bartholomeeusen S, Kim C-Y, Mertens R, Faes C, Buntinx F. The denominator in general practice, a new approach from the Intego database. Family Practice. 2005;22(4):442-447.

17. Schweikardt C, Verheij RA, Donker GA, Coppieters Y. The historical development of the Dutch Sentinel General Practice Network from a paper-based into a digital primary care monitoring system. Journal of Public Health. 2016;24(6):545-562.

18. Clinical Practice Research Datalink. https://www.cprd.com/home/. Accessed August 18, 2019.

19. Verheij AR, Curcin V, Delaney CB, McGilchrist MM. Possible Sources of Bias in Primary Care Electronic Health Record Data Use and Reuse.J Med Internet Res. 2018;20(5):e185. 
20. Smets M, Smeets M, Van den Bulck S, Janssens S, Aertgeerts B, Vaes B. Defining quality indicators for heart failure in general practice.Acta Cardiol. 2018:1-8.

21. Van den Bulck SA, Vankrunkelsven P, Goderis G, et al. Development of quality indicators for type 2 diabetes, extractable from the electronic health record of the general physician. A rand-modified Delphi method.Primary Care Diabetes. 2019.

22. Ivers NM, Grimshaw JM, Jamtvedt G, et al. Growing literature, stagnant science? Systematic review, meta-regression and cumulative analysis of audit and feedback interventions in health care.Journal of general internal medicine. 2014;29(11):1534-1541.

23. Ivers NM, Sales A, Colquhoun H, et al. No more 'business as usual' with audit and feedback interventions: towards an agenda for a reinvigorated intervention. Implementation science : IS.2014;9:14.

24. Moher D, Liberati A, Tetzlaff J, Altman DG, The PG. Preferred Reporting Items for Systematic Reviews and Meta-Analyses: The PRISMA Statement. PLOS Medicine. 2009;6(7):e1000097.

25. EPOC C. Cochrane Effective Practice and Organisation of Care Review Group. Data Collection Checklist. In:2002.

26. Higgins JPT, Green S (editors). Cochrane Handbook for Systematic Reviews of Interventions. Chichester (UK): John Wiley \& Sons, 2011.

27. Higgins JPT, Altman DG, Gøtzsche PC, et al. The Cochrane Collaboration's tool for assessing risk of bias in randomised trials. BMJ (Clinical research ed). 2011;343.

28. Patel MS, Kurtzman GW, Kannan S, et al. Effect of an Automated Patient Dashboard Using Active Choice and Peer Comparison Performance Feedback to Physicians on Statin Prescribing: The PRESCRIBE Cluster Randomized Clinical Trial. JAMA network open. 2018;1(3):e180818.

29. Lim WY, Hss AS, Ng LM, et al. The impact of a prescription review and prescriber feedback system on prescribing practices in primary care clinics: a cluster randomised trial. BMC family practice.2018;19(1):N.PAG-N.PAG.

30. Vinereanu D, Lopes Renato D, Bahit MC, et al. A multifaceted intervention to improve treatment with oral anticoagulants in atrial fibrillation (IMPACT-AF): an international, cluster-randomised trial.Lancet (London, England). 2017;390 North American Edition(10104):1737-1746.

31. Urbiztondo I, Bjerrum L, Caballero L, Suarez MA, Olinisky M, Cordoba G. Decreasing inappropriate use of antibiotics in primary care in four countries in south america - cluster randomized controlled trial.Antibiotics. 2017;6(4).

32. Trietsch J, van Steenkiste B, Grol R, et al. Effect of audit and feedback with peer review on general practitioners' prescribing and test ordering performance: a cluster-randomized controlled trial. BMC family practice. 2017;18(1):53.

33. Holt TA, Dalton A, Marshall T, et al. Automated Software System to Promote Anticoagulation and Reduce Stroke Risk: Cluster-Randomized Controlled Trial. Stroke. 2017;48(3):787-790.

34. Hemkens LG, Saccilotto R, Reyes SL, et al. Personalized prescription feedback using routinely collected data to reduce antibiotic use in primary care a randomized clinical trial. JAMA Internal Medicine.2017;177(2):176-183.

35. Elouafkaoui P, Young L, Newlands R, Duncan E, Elders A, Clarkson J. An audit and feedback intervention for reducing antibiotic prescribing in general dental practice: the RAPiD cluster randomised controlled trial. PLoS medicine. 2017;13(8).

36. Winslade N, Eguale T, Tamblyn R. Optimising the changing role of the community pharmacist: A randomised trial of the impact of audit and feedback. BMJ open. 2016;6(5). 
37. Sarafi NA, Farrokhi NM, Haghdoost A, Bahaadinbeigy K, Abu-Hanna A, Eslami S. The effect of registrybased performance feedback via short text messages and traditional postal letters on prescribing parenteral steroids by general practitioners-A randomized controlled trial.International journal of medical informatics. 2016;87:36-43..

38. Murphy D, Wu L, Thomas E, Forjuoh S, Meyer A, Singh H. Electronic Trigger-Based Intervention to Reduce Delays in Diagnostic Evaluation for Cancer: a Cluster Randomized Controlled Trial. Journal of clinical oncology. 2016;33(31):3560-3567..

39. Hayashino Y, Suzuki H, Yamazaki K, Goto A, Izumi K, Noda M. A cluster randomized trial on the effect of a multifaceted intervention improved the technical quality of diabetes care by primary care physicians: The Japan Diabetes Outcome Intervention Trial-2 (J-DOIT2).Diabetic Medicine. 2016;33(5):599-608.

40. Guthrie B, Kavanagh K, Robertson C, et al. Data feedback and behavioural change intervention to improve primary care prescribing safety (EFIPPS): multicentre, three arm, cluster randomised controlled trial. BMJ (Online). 2016;354(no pagination).

41. Peiris D, Usherwood T, Panaretto K, et al. Effect of a computer-guided, quality improvement program for cardiovascular disease risk management in primary health care: the treatment of cardiovascular risk using electronic decision support cluster-randomized trial.Circulation Cardiovascular quality and outcomes. 2015;8(1):87-95.

42. Ogedegbe G, Tobin JN, Fernandez S, et al. Counseling African Americans to Control Hypertension: cluster-randomized clinical trial main effects. Circulation. 2014;129(20):2044-2051.

43. Gerber JS, Prasad PA, Fiks AG, et al. Effect of an outpatient antimicrobial stewardship intervention on broad-spectrum antibiotic prescribing by primary care pediatricians: a randomized trial.JAMA. 2013;309(22):2345-2352.

44. Almeida O, Pirkis J, Kerse N, et al. A randomized trial to reduce the prevalence of depression and self-harm behavior in older primary care patients. Annals of family medicine. 2012;10(4):347-356.

45. Pape G, Hunt J, Butler K, et al. Team-based care approach to cholesterol management in diabetes mellitus: 2-Year cluster randomized controlled trial. Archives of internal medicine.2011;171(16):1480-1486.

46. Guldberg T, Vedsted P, Kristensen J, Lauritzen T. Improved quality of Type 2 diabetes care following electronic feedback of treatment status to general practitioners: a cluster randomized controlled trial.Diabetic medicine : a journal of the British Diabetic Association. 2011;28(3):325-332.

47. Estrada CA, Safford MM, Salanitro AH, et al. A web-based diabetes intervention for physician: a cluster-randomized effectiveness trial.International Journal for Quality in Health Care.2011;23(6):682-689.

48. Ornstein S, Nemeth LS, Jenkins RG, Nietert PJ. Colorectal cancer screening in primary care: translating research into practice. Medical care. 2010;48(10):900-906.

49. Linder J, Schnipper J, Tsurikova R, et al. Electronic health record feedback to improve antibiotic prescribing for acute respiratory infections. The American journal of managed care. 2010;16(12 Suppl HIT):e311-319.

50. Avery AJ, Rodgers S, Cantrill JA, et al. A pharmacist-led information technology intervention for medication errors (PINCER): a multicentre, cluster randomised, controlled trial and cost-effectiveness analysis. The Lancet. 2012;379(9823):1310-1319.

51. Svetkey LP, Pollak KI, Yancy WS, Jr., et al. Hypertension improvement project: randomized trial of quality improvement for physicians and lifestyle modification for patients. Hypertension.2009;54(6):12261233.

52. Mold JW, Aspy CA, Nagykaldi Z. Implementation of evidence-based preventive services delivery processes in primary care: an Oklahoma Physicians Resource/Research Network (OKPRN) study. J Am Board 
Fam Med. 2008;21(4):334-344.

53. Wadland WC, Holtrop JS, Weismantel D, Pathak PK, Fadel H, Powell J. Practice-based referrals to a tobacco cessation quit line: assessing the impact of comparative feedback vs general reminders. Annals of family medicine. 2007;5(2):135-142.

54. Bahrami M, Deery C, Clarkson JE, et al. Effectiveness of strategies to disseminate and implement clinical guidelines for the management of impacted and unerupted third molars in primary dental care, a cluster randomised controlled trial. Br Dent J. 2004;197(11):691-696; discussion 688.

55. Bonevski B, Sanson-Fisher RW, Campbell E, Carruthers A, Reid AL, Ireland M. Randomized controlled trial of a computer strategy to increase general practitioner preventive care. Preventive Medicine. 1999;29(6 Pt 1):478-486.

56. McAlister NH, Covvey HD, Tong C, Lee A, Wigle ED. Randomised controlled trial of computer assisted management of hypertension in primary care. British medical journal (Clinical research ed).1986;293(6548):670-674.

57. Grimshaw JM, Ivers N, Linklater S, et al. Reinvigorating stagnant science: implementation laboratories and a meta-laboratory to efficiently advance the science of audit and feedback. BMJ Quality Éamp;amp; Safety. 2019;28(5):416.

58. Campbell M, Fitzpatrick R, Haines A, et al. Framework for design and evaluation of complex interventions to improve health. BMJ (Clinical research ed). 2000;321(7262):694.

59. van der Bij S, Khan N, Ten Veen P, de Bakker DH, Verheij RA. Improving the quality of EHR recording in primary care: a data quality feedback tool. Journal of the American Medical Informatics Association : JAMIA. 2016.

60. de Lusignan S, Correa A, Smith GE, et al. RCGP Research and Surveillance Centre: 50 years' surveillance of influenza, infections, and respiratory conditions. The British journal of general practice : the journal of the Royal College of General Practitioners.2017;67(663):440-441.

61. Truyers C, Goderis G, Dewitte H, Akker M, Buntinx F. The Intego database: background, methods and basic results of a Flemish general practice-based continuous morbidity registration project. BMC medical informatics and decision making. 2014;14:48.

\section{Acknowledgements}

SVDB, BV, GG, RH and PV contributed to the design and conceptualization of the study.

SVDB performed the search

SVDB, DS and PV performed the screening, data extraction and risk of bias assessment

SVDB, DS, BV, GG, RH and PV reviewed and edited the manuscript

The authors would like to thank dr. Anne-Catherine Vanhove for her assistance with the search

\section{Conflict of Interest}

None declared

\section{Abbreviations}

A\&F: Audit \& Feedback

EHR: Electronic Health Record 
RCT: Randomized Controlled Trial

\section{Figure legends}

Figure 1: PRISMA flow-chart

Figure 2: Risk of bias graph: review authors' judgements about each risk of bias item presented as percentages across all included studies.

Figure 3: Risk of bias summary: review authors' judgements about each risk of bias item for each included study.

\section{Appendices}

Appendix 1: PRISMA checklist

Appendix 2: Search strings and results

Appendix 3: Elsevier-Embase search: syntax used for translation

Appendix 4: Data extraction sheet continuous outcomes

Appendix 5: Data extraction sheet dichotomous outcomes

\section{Tables}

Table 1: Studies with continuous outcomes 


\begin{tabular}{|c|c|c|c|c|c|c|}
\hline $\begin{array}{l}\text { Study ID } \\
\text { (first author, } \\
\text { year) }\end{array}$ & Study design & $\begin{array}{l}\text { Type of } \\
\text { targeted } \\
\text { behaviour }\end{array}$ & $\begin{array}{l}\text { Primary } \\
\text { outcomes }\end{array}$ & $\begin{array}{l}\text { Type of } \\
\text { interventions } \\
\text { compared }\end{array}$ & $\begin{array}{l}\text { Clinical } \\
\text { condition }\end{array}$ & $\begin{array}{l}\text { Targeted } \\
\text { health } \\
\text { professional }\end{array}$ \\
\hline $\begin{array}{l}\text { Osvaldo P. } \\
\text { Almeida, } \\
2012\end{array}$ & CRCT & $\begin{array}{l}\text { The care for } \\
\text { patients } \\
\text { with } \\
\text { depression } \\
\text { and } \\
\text { self-harm } \\
\text { behavior in } \\
\text { a large } \\
\text { sample of } \\
\text { primary care } \\
\text { patients } \\
\text { aged } 60 \\
\text { years or } \\
\text { older }\end{array}$ & $\begin{array}{l}\text { A composite } \\
\text { measure of } \\
\text { clinically } \\
\text { significant } \\
\text { depression } \\
\text { (Patient } \\
\text { Health } \\
\text { Question- } \\
\text { naire score } \\
\text { [?]10) or } \\
\text { self-harm } \\
\text { behavior } \\
\text { (suicide } \\
\text { thoughts or } \\
\text { attempt } \\
\text { during the } \\
\text { previous } 12 \\
\text { months) }\end{array}$ & $\begin{array}{l}\text { The } \\
\text { intervention } \\
\text { consisted of } \\
\text { a practice } \\
\text { audit with } \\
\text { personalized } \\
\text { automated } \\
\text { audit } \\
\text { feedback, } \\
\text { printed } \\
\text { educational } \\
\text { material, } \\
\text { and } \\
6 \text {-monthly } \\
\text { educational } \\
\text { newsletters } \\
\text { delivered } \\
\text { over a } \\
\text { period of } 2 \\
\text { years. } \\
\text { Control } \\
\text { physicians } \\
\text { completed a } \\
\text { practice } \\
\text { audit but } \\
\text { did not } \\
\text { receive indi- } \\
\text { vidualized } \\
\text { feedback. } \\
\text { They also } \\
\text { received } \\
\text { diagnopression, } \\
\text { and } \\
\text { ananagementhly suicide } \\
\text { behavior in } \\
\text { later life. } \\
\text { newsletters } \\
\text { describing } \\
\text { the progress } \\
\text { of the study, } \\
\text { but they } \\
\text { were not } \\
\text { offered } \\
\text { access to the } \\
\text { educational } \\
\text { material } \\
\text { about } \\
\text { dcreening, } \\
\text { dedised }\end{array}$ & Depression & GP \\
\hline
\end{tabular}




\begin{tabular}{|c|c|c|c|c|c|c|}
\hline $\begin{array}{l}\text { Study ID } \\
\text { (first author, } \\
\text { year) }\end{array}$ & Study design & $\begin{array}{l}\text { Type of } \\
\text { targeted } \\
\text { behaviour }\end{array}$ & $\begin{array}{l}\text { Primary } \\
\text { outcomes }\end{array}$ & $\begin{array}{l}\text { Type of } \\
\text { interventions } \\
\text { compared }\end{array}$ & $\begin{array}{l}\text { Clinical } \\
\text { condition }\end{array}$ & $\begin{array}{l}\text { Targeted } \\
\text { health } \\
\text { professional }\end{array}$ \\
\hline $\begin{array}{l}\text { Anthony J } \\
\text { Avery, } 2012\end{array}$ & CRCT & $\begin{array}{l}\text { Medication } \\
\text { errors }\end{array}$ & $\begin{array}{l}\text { The } \\
\text { proportions } \\
\text { of patients } \\
\text { at } 6 \text { months } \\
\text { after the } \\
\text { intervention } \\
\text { who had had } \\
\text { any of three } \\
\text { clinically } \\
\text { important } \\
\text { errors: non } \\
\text { selective } \\
\text { NSAIDs } \\
\text { prescribed } \\
\text { to those } \\
\text { with a } \\
\text { history of } \\
\text { peptic ulcer } \\
\text { without co- } \\
\text { prescription } \\
\text { of a proton- } \\
\text { pump } \\
\text { inhibitor; } \beta \\
\text { blockers } \\
\text { prescribed } \\
\text { to those } \\
\text { with a } \\
\text { history of } \\
\text { asthma; } \\
\text { long-term } \\
\text { prescription } \\
\text { of ACE-I or } \\
\text { loop } \\
\text { diuretics to } \\
\text { those } 75 \\
\text { years or } \\
\text { older } \\
\text { without } \\
\text { assessment } \\
\text { of urea and } \\
\text { electrolytes } \\
\text { months. }\end{array}$ & $\begin{array}{l}\text { Computer- } \\
\text { generated } \\
\text { simple } \\
\text { feedback for } \\
\text { at-risk } \\
\text { patients } \\
\text { (control) } \\
\text { versus a } \\
\text { pharmacist- } \\
\text { led } \\
\text { information } \\
\text { technology } \\
\text { intervention, } \\
\text { composed of } \\
\text { feedback, } \\
\text { educational } \\
\text { outreach, } \\
\text { and } \\
\text { dedicated } \\
\text { support. }\end{array}$ & $\begin{array}{l}\text { Medication } \\
\text { safety }\end{array}$ & GP \\
\hline
\end{tabular}




\begin{tabular}{|c|c|c|c|c|c|c|}
\hline $\begin{array}{l}\text { Study ID } \\
\text { (first author, } \\
\text { year) }\end{array}$ & Study design & $\begin{array}{l}\text { Type of } \\
\text { targeted } \\
\text { behaviour }\end{array}$ & $\begin{array}{l}\text { Primary } \\
\text { outcomes }\end{array}$ & $\begin{array}{l}\text { Type of } \\
\text { interventions } \\
\text { compared }\end{array}$ & $\begin{array}{l}\text { Clinical } \\
\text { condition }\end{array}$ & $\begin{array}{l}\text { Targeted } \\
\text { health } \\
\text { professional }\end{array}$ \\
\hline $\begin{array}{l}\text { B. Bonevski, } \\
1999\end{array}$ & $\mathrm{RCT}$ & $\begin{array}{l}\text { Preventive } \\
\text { medicine }\end{array}$ & $\begin{array}{l}\text { Assessing } \\
\text { smoking and } \\
\text { benzodi- } \\
\text { azepine use } \\
\text { sensitivity, } \\
\text { specificity, } \\
\text { and overall } \\
\text { accuracy } \\
\text { and whether } \\
\text { blood } \\
\text { pressure and } \\
\text { cholesterol } \\
\text { screening } \\
\text { levels were } \\
\text { obtained. }\end{array}$ & $\begin{array}{l}\text { Those given } \\
\text { the } \\
\text { intervention } \\
\text { received a } \\
\text { computer- } \\
\text { ized } \\
\text { feedback } \\
\text { system; } \\
\text { control } \\
\text { group was } \\
\text { given usual } \\
\text { care }\end{array}$ & $\begin{array}{l}\text { Preventive } \\
\text { medicine }\end{array}$ & GP \\
\hline $\begin{array}{l}\text { Carlos A. } \\
\text { Estrada, } \\
2011\end{array}$ & CRCT & $\begin{array}{l}\text { Improving } \\
\text { diabetes } \\
\text { control }\end{array}$ & $\begin{array}{l}\text { 'Acceptable } \\
\text { control': } \\
\text { [hemoglobin } \\
\text { A1c <9\%, } \\
\text { blood } \\
\text { pressure } \\
<140 / 90 \\
\text { mmHg, LDL } \\
\text { cholesterol } \\
<130 \text { mg/dl] } \\
\text { and 'optimal } \\
\text { control': } \\
\text { [hemoglobin } \\
\text { A1c <7\%, } \\
\text { blood } \\
\text { pressure } \\
<130 / 80 \\
\text { mmHg, LDL } \\
\text { cholesterol } \\
<100 \\
\text { mg/dl]. }\end{array}$ & $\begin{array}{l}\text { A multi- } \\
\text { component } \\
\text { intervention } \\
\text { including } \\
\text { Web-based } \\
\text { CME, } \\
\text { performance } \\
\text { feedback } \\
\text { and quality } \\
\text { improve- } \\
\text { ment tools } \\
\text { versus usual } \\
\text { care } \\
\text { (physicians } \\
\text { in the } \\
\text { control } \\
\text { group did } \\
\text { not receive } \\
\text { performance } \\
\text { feedback } \\
\text { reports or } \\
\text { electronic } \\
\text { communicatic }\end{array}$ & Diabetes & $\begin{array}{l}\text { Primary } \\
\text { care } \\
\text { physicians }\end{array}$ \\
\hline
\end{tabular}




\begin{tabular}{|c|c|c|c|c|c|c|}
\hline $\begin{array}{l}\text { Study ID } \\
\text { (first author, } \\
\text { year) }\end{array}$ & Study design & $\begin{array}{l}\text { Type of } \\
\text { targeted } \\
\text { behaviour }\end{array}$ & $\begin{array}{l}\text { Primary } \\
\text { outcomes }\end{array}$ & $\begin{array}{l}\text { Type of } \\
\text { interventions } \\
\text { compared }\end{array}$ & $\begin{array}{l}\text { Clinical } \\
\text { condition }\end{array}$ & $\begin{array}{l}\text { Targeted } \\
\text { health } \\
\text { professional }\end{array}$ \\
\hline $\begin{array}{l}\text { Trine Lignell } \\
\text { Guldberg, } \\
2011\end{array}$ & CRCT & $\begin{array}{l}\text { Quality of } \\
\text { type } 2 \\
\text { diabetes } \\
\text { care }\end{array}$ & $\begin{array}{l}\text { Processes of } \\
\text { care } \\
\text { according to } \\
\text { guidelines } \\
\text { on redeemed } \\
\text { prescriptions } \\
\text { for recom- } \\
\text { mended type } \\
2 \text { diabetes } \\
\text { treatment, } \\
\text { measuring of } \\
\text { HbA1c and } \\
\text { cholesterol } \\
\text { and visits to } \\
\text { ophthalmologists }\end{array}$ & $\begin{array}{l}\text { To receive or } \\
\text { not to } \\
\text { receive } \\
\text { electronic } \\
\text { feedback on } \\
\text { quality of } \\
\text { care }\end{array}$ & $\begin{array}{l}\text { Type } 2 \\
\text { diabetes }\end{array}$ & GP \\
\hline $\begin{array}{l}\text { Bruce } \\
\text { Guthrie, } \\
2016\end{array}$ & CRCT & $\begin{array}{l}\text { Safety of } \\
\text { prescribing }\end{array}$ & $\begin{array}{l}\text { Proportion } \\
\text { of patients } \\
\text { included in } \\
\text { one or more } \\
\text { of the } \\
\text { defined } 6 \\
\text { individual } \\
\text { secondary } \\
\text { outcomes } \\
\text { (denomina- } \\
\text { tor) who } \\
\text { receive any } \\
\text { high risk } \\
\text { prescription } \\
\text { (numerator) }\end{array}$ & $\begin{array}{l}3 \text { arms: } \\
\text { "usual care," } \\
\text { (consisting } \\
\text { of emailed } \\
\text { educational } \\
\text { material } \\
\text { with support } \\
\text { for searching } \\
\text { to identify } \\
\text { patient); } \\
\text { usual care } \\
\text { plus } \\
\text { feedback on } \\
\text { practice's } \\
\text { high risk } \\
\text { prescribing; } \\
\text { usual care } \\
\text { plus the } \\
\text { same } \\
\text { feedback in- } \\
\text { corporating } \\
\text { a behavioral } \\
\text { change } \\
\text { component }\end{array}$ & $\begin{array}{l}\text { Safety of } \\
\text { prescribing }\end{array}$ & GP \\
\hline
\end{tabular}




\begin{tabular}{|c|c|c|c|c|c|c|}
\hline $\begin{array}{l}\text { Study ID } \\
\text { (first author, } \\
\text { year) }\end{array}$ & Study design & $\begin{array}{l}\text { Type of } \\
\text { targeted } \\
\text { behaviour }\end{array}$ & $\begin{array}{l}\text { Primary } \\
\text { outcomes }\end{array}$ & $\begin{array}{l}\text { Type of } \\
\text { interventions } \\
\text { compared }\end{array}$ & $\begin{array}{l}\text { Clinical } \\
\text { condition }\end{array}$ & $\begin{array}{l}\text { Targeted } \\
\text { health } \\
\text { professional }\end{array}$ \\
\hline $\begin{array}{l}\text { Wei Yin } \\
\text { Lim, } 2018\end{array}$ & CRCT & $\begin{array}{l}\text { Manual } \\
\text { prescribing } \\
\text { medication }\end{array}$ & $\begin{array}{l}\text { The } \\
\text { percentage } \\
\text { of } \\
\text { prescriptions } \\
\text { with at least } \\
\text { one error } \\
\text { (error versus } \\
\text { no error) }\end{array}$ & $\begin{array}{l}\text { a) full } \\
\text { feedback } \\
\text { intervention } \\
\text { [structured } \\
\text { prescription } \\
\text { review and } \\
\text { prescribing } \\
\text { performance } \\
\text { feedback } \\
\text { (league } \\
\text { tables and } \\
\text { authorized } \\
\text { feedback } \\
\text { letter)], b) } \\
\text { partial } \\
\text { feedback } \\
\text { intervention } \\
\text { [structured } \\
\text { prescription } \\
\text { review and } \\
\text { prescribing } \\
\text { performance } \\
\text { feedback } \\
\text { (league } \\
\text { tables } \\
\text { only)], or c) } \\
\text { usual care as } \\
\text { control } \\
\text { (structured } \\
\text { prescription } \\
\text { review only). }\end{array}$ & $\begin{array}{l}\text { Errors in } \\
\text { prescribing }\end{array}$ & $\begin{array}{l}\text { Primary } \\
\text { care } \\
\text { prescribers }\end{array}$ \\
\hline $\begin{array}{l}\text { Jeffrey A. } \\
\text { Linder, } 2010\end{array}$ & CRCT & $\begin{array}{l}\text { Antibiotic } \\
\text { prescribing }\end{array}$ & $\begin{array}{l}\text { The primary } \\
\text { outcome was } \\
\text { the intent- } \\
\text { to-intervene } \\
\text { antibiotic } \\
\text { prescribing } \\
\text { rate for } \\
\text { acute } \\
\text { respiratory } \\
\text { infection } \\
\text { visits. }\end{array}$ & $\begin{array}{l}\text { the ARI } \\
\text { Quality } \\
\text { Dashboard, } \\
\text { an } \\
\text { EHR-based } \\
\text { feedback } \\
\text { system } \\
\text { versus usual } \\
\text { care }\end{array}$ & $\begin{array}{l}\text { Acute } \\
\text { respiratory } \\
\text { infections }\end{array}$ & $\begin{array}{l}\text { Primary } \\
\text { care } \\
\text { physicians }\end{array}$ \\
\hline
\end{tabular}




\begin{tabular}{|c|c|c|c|c|c|c|}
\hline $\begin{array}{l}\text { Study ID } \\
\text { (first author, } \\
\text { year) }\end{array}$ & Study design & $\begin{array}{l}\text { Type of } \\
\text { targeted } \\
\text { behaviour }\end{array}$ & $\begin{array}{l}\text { Primary } \\
\text { outcomes }\end{array}$ & $\begin{array}{l}\text { Type of } \\
\text { interventions } \\
\text { compared }\end{array}$ & $\begin{array}{l}\text { Clinical } \\
\text { condition }\end{array}$ & $\begin{array}{l}\text { Targeted } \\
\text { health } \\
\text { professional }\end{array}$ \\
\hline $\begin{array}{l}\text { James W. } \\
\text { Mold, } 2008\end{array}$ & $\mathrm{RCT}$ & $\begin{array}{l}\text { Preventive } \\
\text { service } \\
\text { delivery }\end{array}$ & $\begin{array}{l}\text { The number } \\
\text { of practices } \\
\text { who } \\
\text { implemented } \\
\text { one or more } \\
\text { evidence- } \\
\text { based } \\
\text { processes } \\
\text { and the } \\
\text { total } \\
\text { number of } \\
\text { processes } \\
\text { imple- } \\
\text { mented, as } \\
\text { determined } \\
\text { by a blinded } \\
\text { expert panel } \\
\text { from } \\
\text { transcripts } \\
\text { of structured } \\
\text { clinician } \\
\text { interviews } \\
\text { conducted } \\
\text { at baseline } \\
\text { and after a } \\
6 \text {-month } \\
\text { intervention } \\
\text { period }\end{array}$ & $\begin{array}{l}\text { Comparing } \\
\text { a multicom- } \\
\text { ponent } \\
\text { quality im- } \\
\text { provement } \\
\text { intervention } \\
\text { (Interven- } \\
\text { tion } \\
\text { practices } \\
\text { received } \\
\text { performance } \\
\text { feedback, } \\
\text { peer-to-peer } \\
\text { education } \\
\text { (academic } \\
\text { detailing), a } \\
\text { practice } \\
\text { facilitator, } \\
\text { and } \\
\text { computer } \\
\text { (information } \\
\text { technology) } \\
\text { support) to } \\
\text { feedback } \\
\text { and bench- } \\
\text { marking (= } \\
\text { control) }\end{array}$ & $\begin{array}{l}\text { Preventive } \\
\text { medicine }\end{array}$ & Clinicians \\
\hline
\end{tabular}




\begin{tabular}{|c|c|c|c|c|c|c|}
\hline $\begin{array}{l}\text { Study ID } \\
\text { (first author, } \\
\text { year) }\end{array}$ & Study design & $\begin{array}{l}\text { Type of } \\
\text { targeted } \\
\text { behaviour }\end{array}$ & $\begin{array}{l}\text { Primary } \\
\text { outcomes }\end{array}$ & $\begin{array}{l}\text { Type of } \\
\text { interventions } \\
\text { compared }\end{array}$ & $\begin{array}{l}\text { Clinical } \\
\text { condition }\end{array}$ & $\begin{array}{l}\text { Targeted } \\
\text { health } \\
\text { professional }\end{array}$ \\
\hline $\begin{array}{l}\text { Gbenga } \\
\text { Ogedegbe, } \\
2014\end{array}$ & CRCT & $\begin{array}{l}\text { Blood } \\
\text { Pressure } \\
\text { controle }\end{array}$ & $\begin{array}{l}\text { The rate of } \\
\text { BP control } \\
\text { at } 12 \\
\text { months, } \\
\text { defined as } \\
\text { mean } \mathrm{BP} \\
<140 / 90 \\
\text { mm } \mathrm{Hg} \text { (or } \\
\text { mean } \mathrm{BP} \\
<130 / 80 \\
\text { mm Hg for } \\
\text { those with } \\
\text { diabetes } \\
\text { mellitus or } \\
\text { kidney } \\
\text { disease) }\end{array}$ & $\begin{array}{l}\text { Patients at } \\
\text { the } \\
\text { intervention } \\
\text { sites } \\
\text { received } \\
\text { patient } \\
\text { education, } \\
\text { home BP } \\
\text { monitoring, } \\
\text { and monthly } \\
\text { lifestyle } \\
\text { counseling, } \\
\text { whereas } \\
\text { physicians } \\
\text { attended } \\
\text { monthly } \\
\text { hypertension } \\
\text { case rounds } \\
\text { and received } \\
\text { feedback on } \\
\text { their } \\
\text { patients' } \\
\text { home BP } \\
\text { readings and } \\
\text { chart audits. } \\
\text { Patients and } \\
\text { physicians } \\
\text { at the usual } \\
\text { care sites } \\
\text { received } \\
\text { printed } \\
\text { patient } \\
\text { education } \\
\text { material and } \\
\text { hypertension } \\
\text { treatment } \\
\text { guidelines, } \\
\text { respectively. }\end{array}$ & Hypertension & GP \\
\hline
\end{tabular}




\begin{tabular}{|c|c|c|c|c|c|c|}
\hline $\begin{array}{l}\text { Study ID } \\
\text { (first author, } \\
\text { year) }\end{array}$ & Study design & $\begin{array}{l}\text { Type of } \\
\text { targeted } \\
\text { behaviour }\end{array}$ & $\begin{array}{l}\text { Primary } \\
\text { outcomes }\end{array}$ & $\begin{array}{l}\text { Type of } \\
\text { interventions } \\
\text { compared }\end{array}$ & $\begin{array}{l}\text { Clinical } \\
\text { condition }\end{array}$ & $\begin{array}{l}\text { Targeted } \\
\text { health } \\
\text { professional }\end{array}$ \\
\hline $\begin{array}{l}\text { Steven } \\
\text { Ornstein, } \\
2010\end{array}$ & CRCT & $\begin{array}{l}\text { Colorectal } \\
\text { cancer } \\
(\mathrm{CRC}) \\
\text { screening }\end{array}$ & $\begin{array}{l}\text { Proportion } \\
\text { of active } \\
\text { patients up } \\
\text { to date with } \\
\text { CRC } \\
\text { screening } \\
\text { and having } \\
\text { screening } \\
\text { recom- } \\
\text { mended } \\
\text { within past } \\
\text { year among } \\
\text { those not up } \\
\text { to date }\end{array}$ & $\begin{array}{l}\text { A quality } \\
\text { improve- } \\
\text { ment } \\
\text { intervention } \\
\text { combining } \\
\text { EHR based } \\
\text { audit and } \\
\text { feedback, } \\
\text { practice site } \\
\text { visits for } \\
\text { academic } \\
\text { detailing } \\
\text { and partici- } \\
\text { patory } \\
\text { planning, } \\
\text { and "best- } \\
\text { practice" } \\
\text { dissemina- } \\
\text { tion on CRC } \\
\text { screening } \\
\text { versus usual } \\
\text { care }\end{array}$ & $\begin{array}{l}\text { Colorectal } \\
\text { cancer }\end{array}$ & $\begin{array}{l}\text { Primary } \\
\text { care } \\
\text { physicians }\end{array}$ \\
\hline
\end{tabular}




\begin{tabular}{|c|c|c|c|c|c|c|}
\hline $\begin{array}{l}\text { Study ID } \\
\text { (first author, } \\
\text { year) }\end{array}$ & Study design & $\begin{array}{l}\text { Type of } \\
\text { targeted } \\
\text { behaviour }\end{array}$ & $\begin{array}{l}\text { Primary } \\
\text { outcomes }\end{array}$ & $\begin{array}{l}\text { Type of } \\
\text { interventions } \\
\text { compared }\end{array}$ & $\begin{array}{l}\text { Clinical } \\
\text { condition }\end{array}$ & $\begin{array}{l}\text { Targeted } \\
\text { health } \\
\text { professional }\end{array}$ \\
\hline $\begin{array}{l}\text { Ginger A. } \\
\text { Pape, } 2011\end{array}$ & CRCT & $\begin{array}{l}\text { Cholesterol } \\
\text { Management } \\
\text { in Diabetes } \\
\text { Mellitus }\end{array}$ & $\begin{array}{l}\text { Proportion } \\
\text { of } \\
\text { participants } \\
\text { in each arm } \\
\text { achieving a } \\
\text { target LDL } \\
\text { level of } 100 \\
\text { mg/dL or } \\
\text { lower }\end{array}$ & $\begin{array}{l}\text { The } \\
\text { intervention } \\
\text { included } \\
\text { remote } \\
\text { physician- } \\
\text { pharmacist } \\
\text { team-based } \\
\text { care focused } \\
\text { on } \\
\text { cholesterol } \\
\text { management } \\
\text { in DM } \\
\text { versus } \\
\text { control. All } \\
\text { clinicians in } \\
\text { the study } \\
\text { had access } \\
\text { to a health } \\
\text { information } \\
\text { technology } \\
\text { tool, which } \\
\text { provided } \\
\text { automated } \\
\text { DM-related } \\
\text { point-of-care } \\
\text { prompts, a } \\
\text { Web-based } \\
\text { registry, and } \\
\text { performance } \\
\text { feedback } \\
\text { with } \\
\text { benchmarking. }\end{array}$ & $\begin{array}{l}\text { Cholesterol } \\
\text { management } \\
\text { in diabetes } \\
\text { mellitus }\end{array}$ & $\begin{array}{l}\text { Family } \\
\text { practice and } \\
\text { internal } \\
\text { medicine } \\
\text { physicians }\end{array}$ \\
\hline
\end{tabular}




\begin{tabular}{|c|c|c|c|c|c|c|}
\hline $\begin{array}{l}\text { Study ID } \\
\text { (first author, } \\
\text { year) }\end{array}$ & Study design & $\begin{array}{l}\text { Type of } \\
\text { targeted } \\
\text { behaviour }\end{array}$ & $\begin{array}{l}\text { Primary } \\
\text { outcomes }\end{array}$ & $\begin{array}{l}\text { Type of } \\
\text { interventions } \\
\text { compared }\end{array}$ & $\begin{array}{l}\text { Clinical } \\
\text { condition }\end{array}$ & $\begin{array}{l}\text { Targeted } \\
\text { health } \\
\text { professional }\end{array}$ \\
\hline $\begin{array}{l}\text { David Peiris, } \\
2015\end{array}$ & CRCT & $\begin{array}{l}\text { Cardiovascular } \\
\text { disease risk } \\
\text { management }\end{array}$ & $\begin{array}{l}\text { There are } 2 \\
\text { coprimary } \\
\text { outcomes: } 1 . \\
\text { The } \\
\text { proportion of } \\
\text { eligible } \\
\text { patients who } \\
\text { received } \\
\text { appropriate } \\
\text { screening of } \\
\text { CVD risk } \\
\text { factors by the } \\
\text { end of study. } \\
2 . \text { The } \\
\text { proportion of } \\
\text { eligible } \\
\text { patients } \\
\text { defined at } \\
\text { baseline as } \\
\text { being at high } \\
\text { CVD risk, } \\
\text { receiving } \\
\text { recommended } \\
\text { medication } \\
\text { prescriptions } \\
\text { at the end of } \\
\text { study. }\end{array}$ & $\begin{array}{l}\text { The } \\
\text { intervention } \\
\text { arm consisted } \\
\text { of a computer- } \\
\text { guided QI } \\
\text { intervention } \\
\text { comprising } \\
\text { point-of care } \\
\text { electronic } \\
\text { decision } \\
\text { support, audit } \\
\text { and feedback } \\
\text { tools, and } \\
\text { clinical } \\
\text { workforce } \\
\text { training versus } \\
\text { usual care. }\end{array}$ & $\begin{array}{l}\text { Cardiovascular } \\
\text { disease risk } \\
\text { management }\end{array}$ & GP \\
\hline $\begin{array}{l}\text { Inés } \\
\text { Urbiztondo, } \\
2017\end{array}$ & CRCT & $\begin{array}{l}\text { Antibiotic } \\
\text { prescribing } \\
\text { in patients } \\
\text { with } \\
\text { suspected } \\
\text { respiratory } \\
\text { tract } \\
\text { infection }\end{array}$ & $\begin{array}{l}\text { The change } \\
\text { in the } \\
\text { proportion } \\
\text { of patients } \\
\text { treated with } \\
\text { antibiotics } \\
\text { for } \\
\text { respiratory } \\
\text { tract } \\
\text { infection }\end{array}$ & $\begin{array}{l}\text { Intervention } \\
\text { (evidence- } \\
\text { based online } \\
\text { feedback) } \\
\text { versus } \\
\text { control (no } \\
\text { exposure to } \\
\text { the } \\
\text { evidence- } \\
\text { based online } \\
\text { feedback) }\end{array}$ & $\begin{array}{l}\text { respiratory } \\
\text { tract } \\
\text { infections }\end{array}$ & GP \\
\hline $\begin{array}{l}\text { Dragos } \\
\text { Vinereanu, } \\
2017\end{array}$ & CRCT & $\begin{array}{l}\text { Use of oral } \\
\text { anticoagu- } \\
\text { lant } \\
\text { medication } \\
\text { in atrial } \\
\text { fibrillation } \\
\text { to avoid } \\
\text { stroke }\end{array}$ & $\begin{array}{l}\text { The change } \\
\text { in the } \\
\text { proportion } \\
\text { of patients } \\
\text { treated with } \\
\text { oral } \\
\text { anticoagulants }\end{array}$ & $\begin{array}{l}\text { Intervention } \\
\text { consisting of } \\
2 \\
\text { components } \\
\text { (education } \\
\text { and regular } \\
\text { monitoring } \\
\& \text { feedback) } \\
\text { versus usual } \\
\text { care }\end{array}$ & $\begin{array}{l}\text { Atrial } \\
\text { fibrillation }\end{array}$ & $\begin{array}{l}\text { Health care } \\
\text { providers }\end{array}$ \\
\hline
\end{tabular}




\begin{tabular}{|c|c|c|c|c|c|c|}
\hline $\begin{array}{l}\text { Study ID } \\
\text { (first author, } \\
\text { year) }\end{array}$ & Study design & $\begin{array}{l}\text { Type of } \\
\text { targeted } \\
\text { behaviour }\end{array}$ & $\begin{array}{l}\text { Primary } \\
\text { outcomes }\end{array}$ & $\begin{array}{l}\text { Type of } \\
\text { interventions } \\
\text { compared }\end{array}$ & $\begin{array}{l}\text { Clinical } \\
\text { condition }\end{array}$ & $\begin{array}{l}\text { Targeted } \\
\text { health } \\
\text { professional }\end{array}$ \\
\hline $\begin{array}{l}\text { William C. } \\
\text { Wadland, } \\
2007\end{array}$ & CRCT & $\begin{array}{l}\text { Smoking } \\
\text { cessation }\end{array}$ & $\begin{array}{l}\text { Changes } \\
\text { from } \\
\text { baseline to } \\
\text { post } \\
\text { intervention } \\
\text { (18 months) } \\
\text { in clinician } \\
\text { referrals in } \\
\text { both } \\
\text { intervention } \\
\text { and control } \\
\text { groups }\end{array}$ & $\begin{array}{l}\text { Comparing } \\
\text { the impact } \\
\text { of } 6 \\
\text { quarterly } \\
\text { feedback } \\
\text { reports (in- } \\
\text { tervention) } \\
\text { with that of } \\
\text { general } \\
\text { reminders } \\
\text { (control) }\end{array}$ & $\begin{array}{l}\text { Smoking } \\
\text { cessation }\end{array}$ & Clinicians \\
\hline $\begin{array}{l}\text { N. Winslade, } \\
2016\end{array}$ & $\mathrm{RCT}$ & $\begin{array}{l}\text { Provision of } \\
\text { professional } \\
\text { services and } \\
\text { the quality } \\
\text { of patients' } \\
\text { medication } \\
\text { use }\end{array}$ & $\begin{array}{l}\text { The number } \\
\text { of hyperten- } \\
\text { sion/asthma } \\
\text { services } \\
\text { billed per } \\
\text { pharmacy } \\
\text { and } \\
\text { percentage } \\
\text { of } \\
\text { dispensing } \\
\text { to non- } \\
\text { adherent } \\
\text { patients over } \\
\text { the } 12 \\
\text { months post } \\
\text { intervention. }\end{array}$ & $\begin{array}{l}\text { Pharmacy- } \\
\text { specific } \\
\text { performance } \\
\text { feedback } \\
\text { reports } \\
\text { versus no } \\
\text { feedback } \\
\text { reports }\end{array}$ & $\begin{array}{l}\text { Astma and } \\
\text { hypertension }\end{array}$ & Pharmacist \\
\hline
\end{tabular}

CRCT: Cluster Randomized Controlled Trial; RCT: Randomized Controlled Trial; SIGN: Scottish Intercollegiate Guidelines Network; NHS: National Health Service; GP: General Practitioner; DDD: Defined Daily Dose; OAC: Oral Anticoagulants; EHR: Electronic Health Record; PSs: Parenteral Steroids; UTI: Urinary Tract Infection; LQIC: Local Quality Improvement Collaboratives

Table 2: Studies with dichotomous outcomes

CRCT: Cluster Randomized Controlled Trial; RCT: Randomized Controlled Trial; GP: General Practitioner; NSAID: Non-Steroidal Anti-Inflammatory Drugs; ACE-I: Angiotensin Converting Enzyme Inhibitor; LDL: low-density lipoprotein; CME: Continuing Medical Education; ARI: Acute Respiratory Infections; EHR: Electronic Health Record; BP: Blood Pressure; CRC: Colorectal Cancer; DM: Diabetes Mellitus; CVD: Cardiovascular Disease

Table 3: Continuous outcomes, feedback features

\begin{tabular}{llll}
\hline Study ID (first author, year) & Unit of analysis & Frequency of the feedback & Evidence-based feedl \\
\hline Osvaldo P. Almeida, 2012 & Patients & Unclear & Unclear \\
Anthony J Avery, 2012 & Patients & Less than monthly & Unclear \\
B. Bonevski, 1999 & Patients & Unclear & Yes
\end{tabular}




\begin{tabular}{llll}
\hline Study ID (first author, year) & Unit of analysis & Frequency of the feedback & Evidence-based feedl \\
\hline Carlos A. Estrada, 2011 & Patients & Less than monthly & Unclear \\
Trine Lignell Guldberg, 2011 & Patients & Unclear & Yes \\
Bruce Guthrie, 2016 & Patients & Less than monthly & Yes \\
Wei Yin Lim, 2018 & Number of prescriptions & Less than monthly & Unclear \\
Jeffrey A. Linder, 2010 & Providers & Monthly & Yes \\
James W. Mold, 2008 & Providers & Unclear & Unclear \\
Gbenga Ogedegbe, 2014 & Patient & Less than monthly & Yes \\
Steven Ornstein, 2010 & Patients & Unclear & No \\
Ginger A. Pape, 2011 & Patients & Unclear & Yes \\
David Peiris, 2015 & Patient-level data analysis & Unclear & Yes \\
Inés Urbiztondo, 2017 & Individual data at patient and GP level & Weekly & Yes \\
Dragos Vinereanu, 2017 & Patients & Unclear & Unclear \\
William C. Wadland, 2007 & Providers & Less than monthly & Unclear \\
N. Winslade, 2016 & Number of dispensings & Once & Yes \\
\hline
\end{tabular}

Table 4: Dichotomous outcomes, feedback features

\section{Hosted file}

Figure 1.docx available at https://authorea.com/users/291736/articles/419188-the-effect-ofelectronic-audit-and-feedback-in-primary-care-and-factors-facilitating-effectiveness-asystematic-review

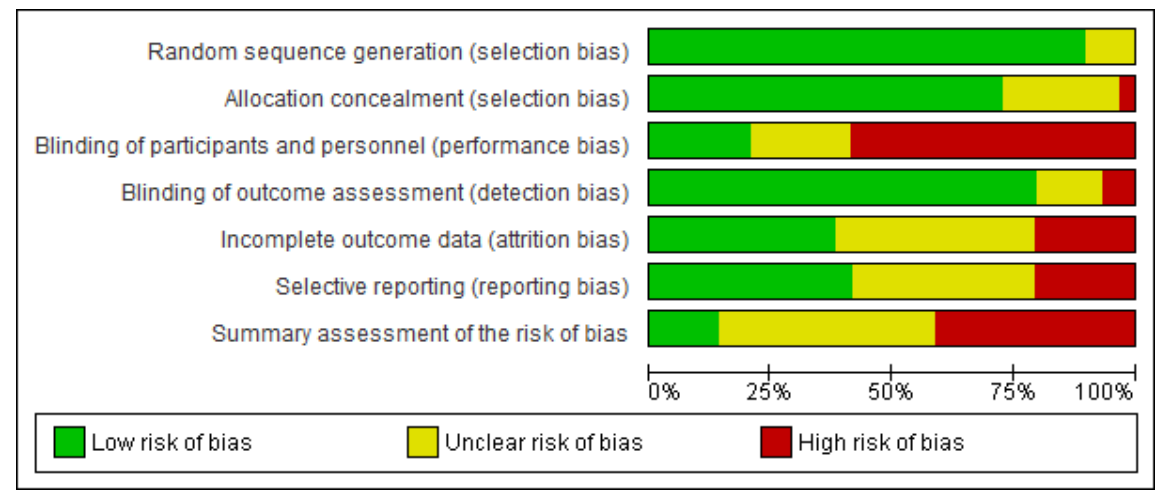




\begin{tabular}{|c|c|c|c|c|c|c|c|}
\hline & 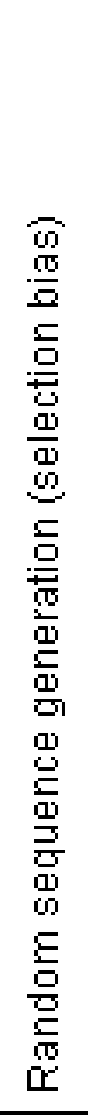 & 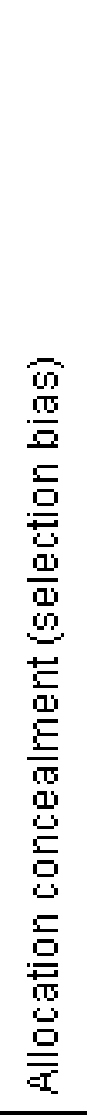 & 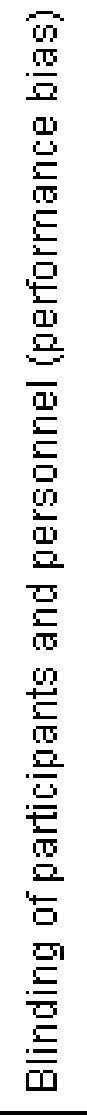 & 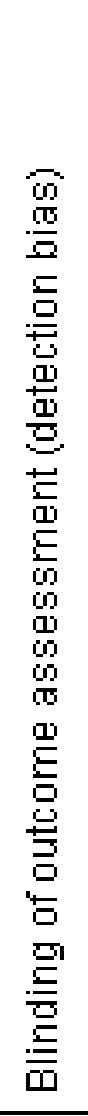 & 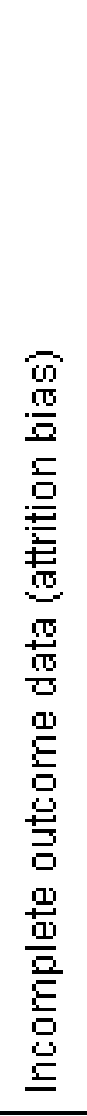 & 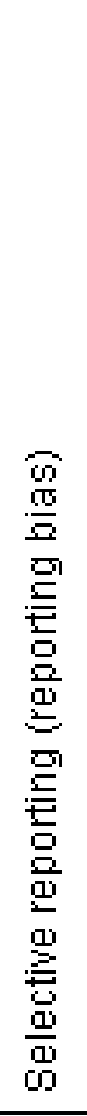 & 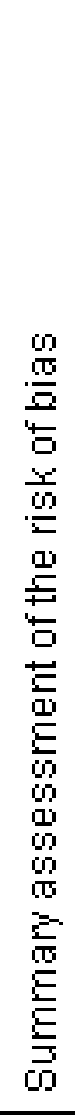 \\
\hline Almeida 2012 & + & + & 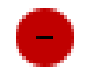 & $?$ & + & $?$ & $?$ \\
\hline Avery 2012 & + & + & & + & $?$ & + & $?$ \\
\hline Bahrami 2004 & + & + & 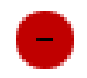 & + & + & $?$ & $?$ \\
\hline Bonevski 1999 & $?$ & $?$ & 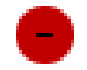 & $?$ & $?$ & $?$ & $?$ \\
\hline Elouafkaoui 2016 & + & $?$ & A & + & $?$ & + & $?$ \\
\hline Estrada 2011 & + & + & $?$ & + & 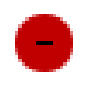 & + & \\
\hline Gerber 2013 & $\oplus$ & $\oplus$ & & + & $?$ & $?$ & $?$ \\
\hline Guldberg 2011 & + & & & + & + & + & \\
\hline Guthrie 2016 & + & + & + & + & + & + & + \\
\hline Hayashino 2015 & + & + & + & + & $?$ & & \\
\hline Hemkens 2017 & + & $\Psi_{25}$ & + & + & + & + & + \\
\hline Holt 2017 & + & + & & + & $?$ & + & $?$ \\
\hline $\operatorname{Lim} 2018$ & + & + & & & + & $?$ & \\
\hline
\end{tabular}

